Animal Health Research Institute, Dokki.

\title{
DIAGNOSTIC TESTS FOR DETECTION OF BOVINE TUBERCULOSIS IN DAIRY CATTLE FARMS COMPARED TO TUBERCULIN TEST
}

(With 4 Tables)

\author{
By \\ E.M. RIAD; S.Z. MAHMOUD* \\ and M.W. ABD AL-AZEEM** \\ *Animal Health Research Lab. Qena \\ ** Dept. of Microbiology Faculty of Vet. Med. South Valley Univ. \\ (Received at 5/10/2009)

\section{الاختبارات التشخيصهي للكثف عن السل البقرى فى مزارع الالبان ومقارنتها باختبار التيوبركلين البلئ}

عماد مختار رياض ، سبي زكى محمود ، محد وائل عبل العظيم

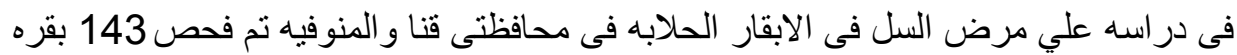

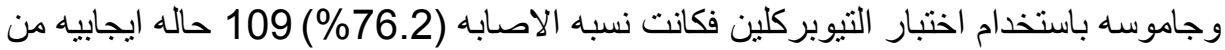

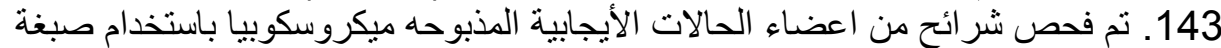

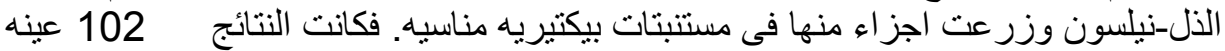

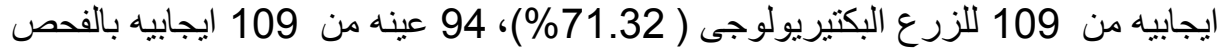

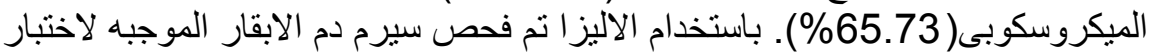

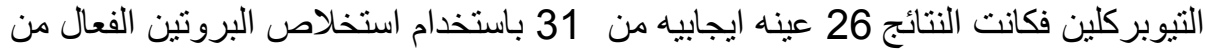

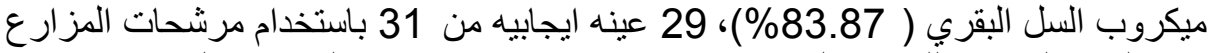

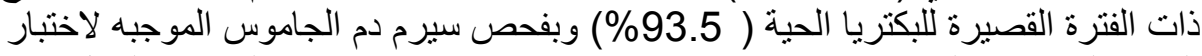

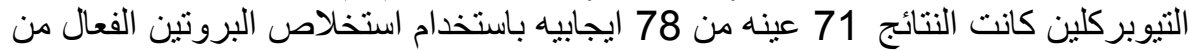

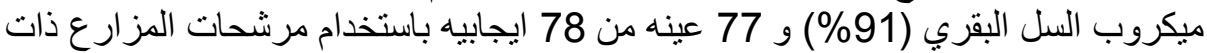

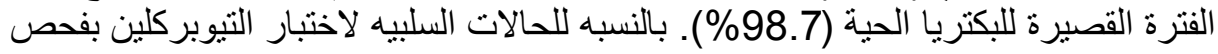

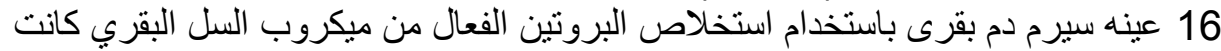

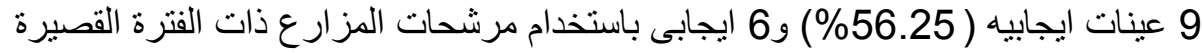

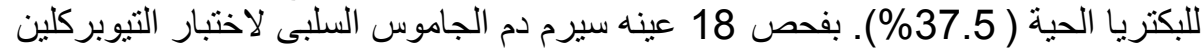

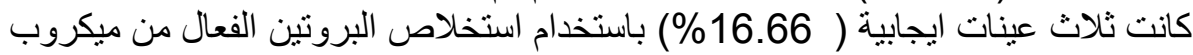

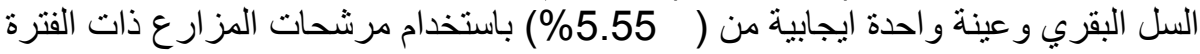

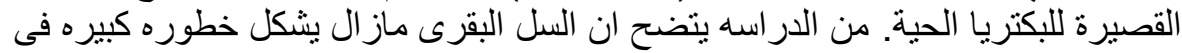

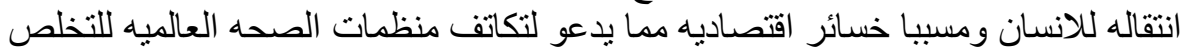


A total number of 143 cows and buffaloes cases in Qena and El-Menoufya Governorates were examined for bovine tuberculosis using single intradermal cervical tuberculin test (SICTT). 109 out of 143 (76.22\%) tested cattle were found positive to tuberculin test. Tissue samples from organs positive cases to tuberculin test were examined microscopically with Ziehl-neelsen stain and by cultivation on two different types of media (Middlebrook and Lowenstein Jenssen media). Blood serum samples from the positive cases were tested by ELISA. ELISA plates were coated with bovine purified protein derivative (PPD) and short term culture filtrate (ST-CF) antigens. The test sensitivity was compared at different serum dilutions. The result was 102 out of 109 cases were positive by cultivation technique with a percentage of (71.32\%) and 94 out of 109 cases were positive by microscopical examination with a percentage of $(65.73 \%)$. The results of ELISA and traditional cultural methods as well as tuberculin test were compared and discussed. All serum samples of tuberculin positive cow cases were tested by indirect ELISA, and showed that 26 out of 31 cow sera were positive by PPD with a percentage of $(83.87 \%)$ and 29 out of 31 cases were positive by using ST- CF antigens with a percentage of $(93.5 \%)$ in (1140) serum dilution. Concerning buffalo cases, 71 out of 78 tuberculin positive sera were positive with PPD antigen with a percentage of (91\%) and 77 sera cases were positive with ST- CF antigen with a percentage of $(98.7 \%)$ at serum dilution (1440). Regarding the tuberculin negative cases, out of 16 tuberculin negative cow cases there were 9 positive cases by using PPD antigen with a percentage of $(56.25 \%)$ and 6 positive cases by using ST- CF antigen with a percentage of (37.5\%). Concerning the buffalo cases, there were 3 positive cases out of 18 tuberculin negative sera by using PPD antigen with a percentage of $(16.66 \%)$ and one case was positive by using ST- CF antigen with a percentage of $(5.55 \%)$.

Key words: TB, PPD, ST-CF.

\section{INTRODUCTION}

Tuberculosis in cattle caused by Mycobacterium bovis (M. bovis) continues to be a problem in both countries with and without active control policies (Thom et al., 2006). Bovine tuberculosis was responsible for approximately $6 \%$ of total human tuberculosis deaths in 1930-1940 (Vordermeier et al., 2003). Bovine tuberculosis (TB) is 
characterized by the progressive development of granulomatous lesions in different body organs and can affect a large number of species. The incidence of bovine TB is rising, both in the number of herds affected and in the number of cases per affected herd (Cobner, 2003). It affected over 50 million cattle world-wide resulting in economic losses of approximately 3 billion $\$$ (Hewinson, 2001).

The intradermal tuberculin test is the only prescribed test for the diagnosis of tuberculosis in cattle (Cousins and Florisson, 2005). The purified protein derivative (PPD) is still the most widely used antigen, however, it contains many antigenic determinants of broad specificity that lead to the appearance of non-specific reactors; animals react positively to tuberculin test but not actually infected, also false negative reactors which give negative tuberculin test although animals are actually tuberculous (Radostits et al., 2000). So identification of the key antigens of $M$. bovis involved in antibody production is required (Lyaschchenko et al., 1998). Enzyme-linked immunosorbent assays (ELISAs) measure antibody titers to $M$. bovis. ELISAs may complement tests of cellular immunity in anergic cattle. It is an accurate and rapid method for detection of the antibodies in the sera of infected animals by using several types of antigens (Daniel and Debanne, 1987; Lilenbaum et al., 1999; Riad, 2004; Sopp et al., 2008 and OIE, 2009).

The present study was conducted to compare the results of tuberculin test and ELISA results on Blood samples using PPD and ST$\mathrm{CT}$ as coating antigens, and the results of tuberculin test and microscopical examination and cultivation technique.

\section{MATERIALS and METHODS}

Animals: A total of 143 dairy cows and buffaloes (96 buffaloes and 47 cows) cases were examined in Qena and El-Menoufya Governorates and tested by single intradermal cervical tuberculin test. Samples of Blood, lymph node of infected organs were collected from the positive animals slaughter as well as blood samples were collected from tuberculin negative animals.

\section{A- Preparation of mycobacterial antigen:}

Preparations of bovine short term culture filtrate: (Andersen et al. (1991) and Gupta et al. (1998). Lypholysed culture filtrate of Mycobacterium bovis was prepared according to the protocol illustrated by tillused. The lyophilized filtrate was dissolved with phosphate buffer saline PPS) containing PMSF. 


\section{- Concentration of (ST-CF) by freeze-drying (Placktt et al., 1989} and Andersen et al., 1991):

The short term culture filtrate of $M$. bovis was exposed to freeze drying labconco freeze drying system, under the maximum condition of the apparatus which were $-47^{\circ} \mathrm{C}$ and $37 \times 10^{\prime} \mathrm{mm} \mathrm{Hg}$ pressure till completed dryness of culture filtrate, then kept frozen at $-20^{\circ} \mathrm{C}$.

- Reconstitution of freeze dried ST-CF antigen:

The short term culture of $M$. bovis was reconstituted with PBS ( $\mathrm{pH}$ 7.4), then PMSF $\mathrm{mM}$ was added and kept frozen at $-20^{\circ} \mathrm{C}$. Estimation of total protein was carried out according to Lawry et al. (1951)

\section{- Standardization of the ST-CF antigen:}

Before using mycobacterial ST-CF antigen used as ELISA coating antigen, it was screened for its sterility, solubility and antigenicity.

a- Sterility test: $0.1 \mathrm{ml}$ of the M. bovis (SI- CF) was diluted 1:100 in sterile distilled water; $0.1 \mathrm{ml}$ was inoculated into nutrient broth and thioglycollate medium for examining the growth of any both aerobic and anaerobic bacteria. Bacto-Sabouraud maltose agar medium was also used for screening fungal growth where incubation was at $25^{\circ} \mathrm{C}$ for 7 days. Modified Lowenstein Jensen medium slopes in McCartney bottles were used to confirm the absence of viable $M$. bovis where incubation was performed at $37^{\circ} \mathrm{C}$ for 6-8 weeks according to (Gupta and Ram, 2000).

b- Solubility test: The prepared ST-CF of M. bovis was fairly soluble in PBS (pH 7.4) containing $10 \mathrm{mM}$ (PMSF).

c- Antigenicity: $M$. bovis ST-CF was screened for its ability to induce delayed type hypersensitivity by the intradermal injection of $M$. bovis sensitized guinea pigs (Heilman, 1967).

\section{B- Bovine PPD antigen:}

Was purchased from Agri Quality. Australia pty Ltd. Prod. No. 63313.

\section{Bacteriological examination:}

a- Conventional culture method (Marks, 1972):

The collected samples showing gross lesion or congestion were prepared for culturing of tubercle bacilli. The fat was trimmed and the suspected material was pieces. Two $\mathrm{ml}$ of sterile aliquot distilled water were added to the crushed tissues, homogenized and ground till suspension was obtained (in this step the direct smear for microscopical examination) Two $\mathrm{ml}$ of $4 \% \mathrm{H}_{2} \mathrm{SO}_{4}$ acid were added to the mixture, and 
then incubated at $37^{\circ} \mathrm{C}$ for 30 minutes. The mixture was diluted with 16 $\mathrm{ml}$ of sterile distilled water and centrifuged at $3000 \mathrm{rpm}$ for $20 \mathrm{~min}$. and the sediment was inoculated into Lowenstein Jensen slants two glycerrated and two pyruvated, incubated at $37^{\circ} \mathrm{C}$ in inclined position for overnight, then vertically for at least 6-8 weeks and examined. The obtained growths were observed for morphological character and for pigment production.

\section{b- Identification of acid- fast bacilli (Kubica, 1973): Microscopical examination:}

A part of the suspected colonies and the impression smear from prepared samples were emulsified with drop of $70 \%$ ethyl alcohol on a slide and spread to form a smear. The smear was allowed to air dry then fixed by heat. The prepared smears stained by Ziehl-Neelsen stain and microscopically examined to detect the morphological characters of acid fast bacilli.

\section{Enzyme linked immunosorbent assay (ELISA):}

Sera of tuberculin positive and negative cases using bovine PPD and ST-CF as coating antigens were used. ELISA was performed as described previously (Hall and Thoen, 1985; Dimitri et al., 1990). Briefly, $100 \mu$ of PPD and ST-CF antigens diluted in carbonate bicarbonate buffer saline: $\mathrm{pH}$ : $9.6(15 \mathrm{Jg} / \mathrm{ml})$ were used for coating, then incubated at $4^{\circ} \mathrm{C}$ over night, washed 3 times in PBS, then the wells were blocked with $1 \%$ ova albumen in PBS for $1 \mathrm{~h}$ at room temperature. 100 $\mu$ of different dilutions of each serum sample (tuberculin positive and tuberculin negative) was added per well $(1 / 40,1 / 80,1 / 160$ and 1/320 in phosphate-buffered saline [PBS] - Tween 20) for PPD and ST-CF. The antigen-antibody binding was allowed to proceed for $60 \mathrm{~min}$. at room temperature and $100 \mu$ of alkaline phosphatase-conjugated goat antibovine IgG diluted 1:3000 in PBS-Tween 20, was added per well. After $60 \mathrm{~min}$ the plates were washed three times then p-nitrophenyl phosphate (100 $\mu$ /well) was added and incubated for $15 \mathrm{~min}$. The optical density was measured at $405 \mathrm{~nm}$ after stopping the reaction by $\mathrm{NaOH}$ to a final concentration of $1 \mathrm{M}(50 \mu$ /well $)$.

Table 1: Tuberculin test results in both cows and buffaloes:

\begin{tabular}{|l|l|l|l|l|}
\hline \multirow{2}{*}{ Animal species } & $\begin{array}{l}\text { Positive } \\
\text { cases }\end{array}$ & tuberculin & $\begin{array}{l}\text { Negative } \\
\text { cases }\end{array}$ & tuberculin \\
\cline { 2 - 5 } & No & $\%$ & No & $\%$ \\
\hline Cows & 31 & 34 & 16 & 65.9 \\
\hline Buffaloes & 78 & 18.75 & 18 & 81.25 \\
\hline Total numbers & 109 & 23.77 & 34 & 76.22 \\
\hline
\end{tabular}




\section{RESULTS}

Table 2: Results of tuberculin positive cattle cases using both cultivation technique and microscopical examination.

\begin{tabular}{|l|l:l|l|l|l|l|l|}
\hline \multirow{2}{*}{ Animal species } & \multicolumn{2}{|l|}{$\begin{array}{l}\text { Positive } \\
\text { tuberculin cases }\end{array}$} & $\begin{array}{l}\text { Conventional } \\
\text { method (isolation) }\end{array}$ & \multicolumn{2}{l|}{$\begin{array}{l}\text { Microscopical } \\
\text { Examination }\end{array}$} \\
\cline { 2 - 7 } & No & $\%$ & No & $\%$ & No & $\%$ \\
\hline Cows & 31 & 65.9 & 27 & 87 & 23 & 74.1 \\
\hline Buffaloes & 78 & 81.25 & 75 & 96.1 & 71 & 91 \\
\hline Total numbers & 109 & 76.22 & 102 & 71.32 & 94 & 65.73 \\
\hline
\end{tabular}

Table 3: Results of ELISA on sera of tuberculin positive cows and buffaloes by using PPD and STCF antigens:

\begin{tabular}{|l|l|l|l|l|l|l|}
\hline \multirow{2}{*}{$\begin{array}{l}\text { Animal } \\
\text { species }\end{array}$} & \multicolumn{7}{|c|}{\begin{tabular}{l} 
Coating antigens of ELISA \\
\cline { 2 - 7 }
\end{tabular}} & $\begin{array}{l}\text { (SICTT) Positive } \\
\text { cases }\end{array}$ & No & $\%$ & Bovine PPD & $\%$ & No & $\%$ \\
\hline Cows & 31 & 65.95 & 26 & 83.87 & 29 & 93.5 \\
\hline Buffaloes & 78 & 81.25 & 71 & 91 & 77 & 98.7 \\
\hline $\begin{array}{l}\text { Total } \\
\text { numbers }\end{array}$ & 109 & 76.22 & 97 & 88.99 & 106 & 74.12 \\
\hline
\end{tabular}

Table 4: Results of ELISA on sera of tuberculin negative cows and buffaloes by using PPD and STCF antigens:

\begin{tabular}{|l|l:l|l|l|l|l|}
\hline \multirow{2}{*}{ Animal species } & \multicolumn{7}{|c|}{$\begin{array}{l}\text { Coating antigens of ELISA } \\
\text { Negative } \\
\text { cases }\end{array}$} & No & $\%$ & $\begin{array}{l}\text { No of +ve } \\
\text { cases }\end{array}$ & $\%$ & $\begin{array}{l}\text { No of +ve } \\
\text { cases }\end{array}$ & $\%$ \\
\cline { 2 - 7 } & 16 & 34 & 9 & 56.25 & 6 & 37.5 \\
\hline Cows & 18 & 18.75 & 3 & 16.66 & 1 & 5.55 \\
\hline Buffaloes & 34 & 23.77 & 12 & 29.90 & 7 & 20.58 \\
\hline Total numbers & 34 & & & ST-CF & \\
\hline
\end{tabular}




\section{DISCUSSION}

The intradermal tuberculin test has been the widest used diagnostic technique. It allows detection of cattle that have been exposed to $M$. bovis. However, in herds where control of T.B. is based on the identification and removal of reactors to this test, some animals in advanced stages of the disease and with open lesions don't show reactivity to tuberculin (anergic) and might remain in the herd, thus constituting a potential source of infection in susceptible cattle (DiazOtero et al., 2003).

In this study, the bacteriological examination was carried out on (31) tuberculin positive cow cases, (87) tuberculin positive buffalo cases, (16) tuberculin negative cow cases and (18) tuberculin negative buffalo cases.

The presented results in Table (2) showed a comparative study between different diagnostic techniques on tuberculin positive examined cow cases and revealed that, out of (47) examined cow cases (31) were tuberculin positive with a percentage of $(65.95 \%)$, (23) showed acid fast bacilli by using zeihl- neelsen stain with a percentage of $(74.1 \%),(27)$ were positive by cultivation technique on Lowenstein Jensen media and Middle brook media with a percentage of $(87 \%)$.

Regarding buffalo cases, there were out of (96) examined buffalo cases (78) were tuberculin positive with a percent of $(81.25 \%)$, (71) showed acid fast bacilli by using zeihl- neelsen stain with a percentage of (91\%), and (75) cases were positive by cultivation technique on Lowenstein Jensen media and Middle brook media with a percentage of $(96.1 \%)$ these results were in agreement with the recorded results by (Sohire and Riad, 2002 and Riad, 2004) who concluded that, the percentage of isolation by conventional cultural method don't exceed (90\%), it depends mainly on the method of processing and type of used media as well as the problem of staining. (Vordemiere et al., 2003 and Cobner, 2003) The authers studied tuberculosis in cows and buffaloes by different diagnostic tools and recorded that, the incidence of tuberculosis reached to $(80 \%)$ by cultural method in some farms.

Concerning the seriological diagnosis, Enzyme-linked immunosorbent assays (ELISA) measure antibody titers to M. bovis. ELISAs may complement tests of cellular immunity in anergic cattle. It is an accurate and rapid method for detection of the antibodies in the sera of infected animals by using several types of antigens (Engvall and Perlmann, 1972; Dimitri et al., 1990; Riad, 2004; Sopp et al., 2008) 
stated that the sensitivity and specificity of ELISA may reach $100 \%$ and $81.8 \%$ in cattle and buffaloes respectively. On the other hand, Placktt et al. (1989) mentioned that the ability of ELISA in detecting anergic cattle is lower than the tuberculin test, so ELISA should be used as a complementary to tuberculin test. However, tests of humoral immunity are generally of limited utility in cattle, because titers are inconsistent and rise only in the late stages of infection (OIE, 2009). In this study, ELISA was applied on (31) tuberculin positive cow cases, (78) tuberculin positive buffalo cases, (16) tuberculin negative cow cases and (18) tuberculin negative buffalo cases. The results of ELISA in our study revealed that, all serum samples of tuberculin positive cow cases were tested by indirect ELISA, and showed that 26 out of 31 cow sera were with PPD with a percentage of (83.87\%) and 29 out of 31 cases were positive by using ST- CF antigens with a percentage of (93.5\%) in (1140) serum dilution (Table 3 ).

Concerning buffalo cases, 71 out of 78 tuberculin positive sera were positive with PPD antigen with a percentage of $(91 \%)$ and 77 sera cases were positive with ST- CF antigen with a percentage of $(98.7 \%)$ at serum dilution (1\40).

Regarding the tuberculin negative cases, the presented results in (Table 4) showing that, out of 16 tuberculin negative cow cases there were 9 positive cases by using PPD antigen with a percentage of $(56.25 \%)$ and 6 positive cases by using ST- CF antigen with a percentage of $(37.5 \%)$. Concerning the buffalo cases, there were 3 positive cases out of 18 tuberculin negative sera by using PPD antigen with a percentage of $(16.66 \%)$ and one case was positive by using ST$\mathrm{CF}$ antigen with a percentage of $(5.55 \%)$.

The result in the present study is in agreement with Lepper and Coner (1983) who stated that antibody response to M. bovis infection is certainly not uniform. This phenomenon was previously suggested in serological analysis by Hanna et al. (1992) who studied the humoral immune response to $M$. bovis infection in cattle and concluded that it was characterized by highly heterogeneous antigen recognition. Also these findings are supported by the results of Gupta and Ram (2000) who reported that the culture filtrate antigens are highly immunogenic for humeral response, being sensitive and specific when used for the diagnosis of bovine tuberculosis by ELISA technique. (Diaz-Otero et al., 2003). 


\section{REFERENCES}

Andersen, P.; Dorthf, A.; Leneljnngovis, T.; Jorgen, B. and Iver, H. (1991): Protein released from M. tuberculosis during growth. Infect. Immun., 59 (6): 1905-1910.

Cobner, A. (2003): Bovine tuberculosis; clinical

Cousins, D.V. and Florisson, N. (2005): A review of tests available for use in the diagnosis of tuberculosis in non bovine species. Rev. Sci. Tech. OIE., 24 (3): 1039-1059.

Daniel, T.M. and Debanne, S.M. (1987): The serodiagnosis of tuberculosis and other mycobacterial diseases by): enzyme linked immunosorbent assay. Am. REV. of Res. Dis., 135: 1137-1155.

Diaz-Otero, F.; Banda-Ruiz, V.; Jaramillo-Meza, L; Arriaga-Diaz, C.; Gonzalez-Salazar, D. and Estrada-Chavez, C. (2003): Identification of Mycobacterium bovis infected cattle by immunological and molecular methods. Veterinaria-Mexico, 34 (1): 13-

Dimitri, R.A.; Soufy, H.; Amin; Gergis, S.M.; Awad, M.M. and Shawkat, M.E. (1990): Studies on serodiagnosis of bovine tuberculosis in Egypt. Egypt. Agric. Res. Rev., 68 (4): 853-863.

Engvall, E. and Perlmann, P. (1972): Enzyme-linked immunosorbent assay (ELISA). III. Quantitation of immunoglobulin in antigen coated tubes. J. Immunol., 109: 129-135.

Gupta, V.K.; Ram, G.C. and Bansal, M.P. (1998): Intracellular killing potential of macrophages activated with different $M$. bovis AN5 antigens.

Gupta, V.K. and Ram, G.C. (2000): Fractionation and immunoreactivity of membrane associated proteins of M. bovis. Ind. J. Anim. Sci., 70 (10): 1015-1020.

Hall, M.R. and Thoen, C.O. (1985): Detection of mycobacterial antibodies in sera of $M$. bovis sensitized cattle using ELISA: Evaluation of assay parameters. Fed. Proc. 26th, USA 934-943.

Hanna, J.; Neill, S.D. and Brion, J.J. (1992): ELISA test for antibodies in experimental bovine tuberculosis. Vet. Microbiol., 31: 243-249.

Heilman, D.H. (1967): In vitro studies on polysaccharides of M. tuberculosis and delayed hypersensitivity. Am. Rev. Resp. Dis., 96 (2): 198-203. 
Hewinson, R.G. (2001): Use of synthetic peptides derived from the antigens ESAT-6 and CFP-10 for differential diagnosis of bovine tuberculosis in cattle. Clin. Diag. Lab. Immunol., 8 (3): 571- 578.

Kubica, G.F. (1973): Differential identification of mycobacteria. VII. Key features for identification of clinically significant mycobacteria. Am. Rev. Resp. Dis., 107: 9-12.

Lawry, O.H; Rosebrough, N.J.; Farr, A.L. and Randall, R.J. (1951):

Protein measurement with the Folin phenol reagent. J. Biol. Chem., 193: 265-275

Lepper, A.W.D. and Coner, L.A. (1983): Naturally occurring mycobacteriosis of animals in biology of mycobacteria. Vol 2 Academic pres London. pp. 478- 448.

Lilenbaum, W.; Ribeiro, E.R.; Souza, G.N.; Moreira, E.C.; Fonseca, L.S.; Ferriera, M.A.S. and Schethim, J. (1999): Evaluation of an ELISA PPD for the diagnosis of bovine tuberculosis in field trials in Brazil. Res. Vet. Sci., 66: 191-195.

Lyaschchenko, K.P; Poollock, J.M; Colangeil, R.; and Gennaro, M.L. (1998): Diversity of antigen recognition by serum antibodies in experimental bovine tuberculosis. Infect. Immun., 66 (11): 5344-5349.

Marks, J. (1972): Ending the routine guinea pigs test. Tubercle, 53: 31-34.

OIE (2009): Northern Ireland Audit Office (NIAO) The control of Bovine stuberculosis In Northern Ireland. NIA 92/ 08-09.

Placktt, R.; Ripper, J.; Comer, L.A.; Small, K.; Witte, K.; Melville, I.; Hides, S.; Wood, P.R. and De-Witte, K. (1989): An ELISA for the detection of the anergic tuberculous cattle. Aust. Vet. J. 66 (1): 15-19.

Radostits, O.M.; Gay, C.D.; Blood, C.D. and Hinchcliff, K.W. (2000): Veterinary Medecine Textbook of the diseases of cattle, sheep, pigs, goats and horses; $9^{\text {th }}$ ed., Baillier, England.

Riad, E.M. (2004): Serodiagnosis of bovine tuberculosis by ELISA using different protein antigens. J. Egypt. Vet. Med. Assoc. 64, 4: 293-303.

Sohair, Y. Mohamed and Riad, E.M. (2002): Bacteriological and Pathological studies on bovine tuberculosis in closed cattle farms at Ismailia Governorate. J. Egypt. Vet. Med. Ass. 62, No. 6: 121-135. 
Sopp, P.; Coad, M.; Hewinson, G.; Howard, C.J.; Cheallaigh, C.N.; Keane, J.; Harris, J. and Hope, J.C. (2008): Development of a simple, sensitive and rapid test which discriminates BCGvaccinated from M. bovis infected cattle. Vaccine. 9; 26(43): 5470- 6.

Thom, M.L.; Hope, J.C.; McAulay, M.; Villarreal-Ramos, B.; Coffey, T.J.; Stephanes, S.; Vordermeier, H.M. and Howard, C.J. (2006): The effect of tuberculin testing on the development of cell-mediated immune responses during Mycobacterium bovis infection. Vet. Immunol. Immunopathol. 114: 25-36.

Vordermeier, H.M.; Whelan, A.; Cockle, P.J.; Farrant, L.; Palmer, N. and Cobner, A. (2003): Bovine tuberculosis; clinical update and on farm advice. In-practice, 25 (10): 606-613. 